\title{
SERIES EDITOR'S FOREWORD
}

This volume fills a gap not only in the provision of sources for the exploration of late medieval English monasticism but in providing the context for that exploration. As Martin Heale discusses in his introduction, medieval monastic history after the glory days of the eleventh and twelfth century reforms has been neglected of late. In part this is because of the belief, emphasised in the magisterial work of Dom David Knowles, that the later centuries saw a progressive decline of the monastic ideal. It surely also owes something to the modern emphasis on 'popular' religion, by which is usually meant the study of attitudes rather than institutions, and the attitudes of the laity rather than the clergy. Monasteries have tended to miss out on both grounds. The extensive surviving sources have been mined far more thoroughly to show the monasteries in their role as landowners and, more recently, as consumers, than to try and engage with their primary, spiritual function. The present collection does not ignore those roles, but reminds us how much more can be drawn from the sources and, in the process, shows where exploration might be taken further. Thus the introduction not only offers a useful synthesis of recent work but in important areas - notably in discussion of how the monasteries' closer engagement with the world might be interpreted - offers exciting new ideas. Although the range of sources deliberately stops before the Dissolution, which would demand a whole volume to itself, the editor also has interesting points to make about which previous developments might have facilitated that process. In all of this, Dr Heale is not using the sources to force a particular reading on his audience but to open up the subject to new questions and approaches. This is an extremely rich volume that will bring late medieval monasticism back in from the cold as a fruitful topic of investigation even for those primarily interested in the attitudes of the pre-Reformation laity or in the Reformation itself.

Rosemary Horrox

Fitzwilliam College, Cambridge 
Martin Heale - 9781847793072

Downloaded from manchesterhive.com at 04/26/2023 10:29:57AM 